\title{
Ars scientia mores: science comes to English dentistry in the seventeenth century. 2. Charles Allen's Treatise of 1685/6
}
IN BRIEF
- Reinforces the historical importance of Charles Allen's Treatise of 1685/6.
- Identifies Charles Allen's possible sources in Royal Society material.
- Suggests that Charles Allen may have undertaken his own research.
- Underlines the scientific core of dental practice in England.

\author{
M. Bishop ${ }^{1}$
}

The dental historian is fortunate to have Charles Allen and his Treatise of 1685/6. His value lies less in the practical content of the work but more in his knowledge of general and dental anatomy, and in the evidence of an enquiring mind. The author tackles developmental anatomy, physiology and pathology in his chosen subject. Without its unassailable provenance it would be difficult to believe that it was written in the 17 th century.

\section{INTRODUCTION}

In 1685 the first edition of a brief Treatise ${ }^{1}$ (the author's description) of just over 7,000 words on the subject of the care of teeth identified and emphasised a persistent trait in those deciding to take up dentistry as a career. It is an acknowledged truism that dentistry is an art and a business ${ }^{2}$ and the motto of the British Dental Association, Ars scientia mores, is a reminder that it is also a science. The profession inevitably appeals to those who enjoy science and its practical application.

Charles Allen's The operator for the teeth $^{1}$ was published first in York in 1685 priced at $6 \mathrm{~d}$ (roughly £2.50 in today's money) and then reprinted in Dublin the following year ${ }^{3}$ with additions adding half as much again to the length. A further issue in 1687 was sold in London. ${ }^{4}$

In ' $O f$ the nature of the teeth', the first section of his work, Allen places science in the first sentence of the first paragraph, highlighting it's importance; 'What men are wont to call Science, or the cognition of any being, is by them commonly divided into two several parts: one whereof is termed Theoretical, and the other Practical. The first includes the reasons and causes of

Hon Research Fellow in the Hist. of Dent., KCL Dental Institute, Bulls Mill House, Hertford, SG14 3NS Correspondence to: Malcolm Bishop

Email:malcolmbishop57@btinternet.com

Accepted 10 October 2012

DOI: 10.1038/sj.bdj.2013.218

${ }^{\circledR}$ British Dental Journal 2013; 214: 239-242 things, with the order and manner of their progress in coming to be what they are. The second regards only their properties, and effects, and what they are actually in themselves, without enquiring how they come to be so made, or thus qualified..$^{3,4}$

He then gives an example of what he means through a discussion of enquiries into the nature and uses of the 'loadstone', a naturally occurring magnetic rock. Allen neatly observes that philosophers inspect the nature of the lodestone, whilst mariners are concerned solely with the fact that the lodestone may be used to magnetise iron in order to make compasses for their practical use.

\section{THE AUTHOR}

Charles Allen, the author of this work, has remained something of a mystery. It is possible that he was born in Ireland, a claim made in a listing of Irish writers published in $1746 .{ }^{5}$ If true, it might account for his move to Dublin in 1685/6.

Although the title page of the London issue refers to the care of the teeth as a 'difficult part of surgery', it is probable that this is the composition of Whitwood the bookseller and not Allen himself. He does not claim that he is a surgeon, entitling his work The operator for the teeth and referring to himself as a 'professor of the same' and to his dental activity as his 'art' and his 'profession'., ${ }^{1,4}$ At the time of writing he had been engaged in this "profession' for some considerable time; "were it not for my former practice, and long habit in those things, I neither could have, nor expect so good a success. ${ }^{4}$ His erstwhile master, mentioned in a couple of places, had also clearly been more than a mere tooth-drawer. ${ }^{1,4}$

His dental pharmacopoeia of box, camphor, mastic, myrrh and henbane (not the scam seeds but the active component of the extract) indicates a sound knowledge of that side of his profession. Box, camphor and henbane are authentically antibacterial and/or analgesic when applied, as he instructs, directly to a tooth cavity that has previously been scraped and washed (NB: all are poisons if misapplied). Mastic was noted as late as 1931 for its use in filling carious teeth, and myrrh as being 'good for spongy gums, ulcerated throat and aphthous stomatitis'. ${ }^{6}$ He also reprimands his master for incorrectly calling a dentifrice an 'opiat', ${ }^{1,4}$ although copying him in his own bills.

Previous researchers, notably the indefatigable dental historian Ronald Cohen, ${ }^{7}$ were unable to find his records in York. Others to research his life were Bernhard Weinberger, ${ }^{8}$ who brought Allen to the attention of the 20th century, and Lilian Lindsay. ${ }^{9}$ Christine Hillam wrote the brief entry in the Oxford dictionary of national biography. ${ }^{10}$

He is clearly more than simply literate - his style of writing stands comparison with that of the scientific researchers of his day as seen in the Royal Society 
Philosophical Transactions, with added flashes of dry wit; 'such teeth are called by some Teeth of wisdom; because by that time we should have full use of our Rational faculty, tho' God knows how often it proves to be true. ${ }^{1,4}$ His ability was clearly recognisd by William Whitwood when he took on the treatise pages, already printed in Dublin, for sale in London from his premises in Duck Lane near Westminster Abbey (where James Allestry, Printer to the Royal Society, had been in 1665; Fig. 1).

As can be seen when he rejects transplanting teeth as 'robbing Peter to pay Paul $^{1,4}$ he is both thoughtful and humane. His imagination can run away with him, and does so in the same section when he fails to extend his humanity to the animal kingdom and suggests the wholly unrealistic substitution of a 'dog, sheep, goat or baboon' as the donor for transplanted teeth. (Vivisection in medical research and 21st century employment of pig valves in heart surgery would not have caused moral qualms in the 17th century.)

While in York he lodged in Stonegate with Mr Walter Galloway, ${ }^{1}$ who was an apothecary and member of the Gild of Barber Surgeons of York, and in Dublin he lodged with Mr Banister (trade unstated) at the Smith's Arms in Essex Street; ${ }^{3}$ in both cases inviting patients to come to him for 'advice (concerning any thing that belongs to my profession) gratis at any time'. Presumably the free advice was, if necessary, followed by treatment that was paid for. The new title page for the London issue makes no mention of Allen's whereabouts, though the invitation to visit him remains in the conclusion. ${ }^{4}$ This statement that he could be consulted in his rooms in Dublin had little relevance to a treatise sold in London.

Allen gives the impression of aiming to be a dental physician, with a strong bias towards preventive practice. For scaling he recommended his patients to experts; 'some artist in that function, for otherwise if you employ anybody that is unskilful in it, you may chance to find the remedy worse than the Disease..1,4 Extraction was a last resort; 'the Drawing out of Teeth is practised by a great many, but perhaps understood but of very few. To be performed with great care and circumspection. ${ }^{1,4}$ He was upset by having to 'abandon the Art in my practice, and invent certain general remedies' rather than continue in following a 'methodical cure' since his patients expected quick results.

The scientific content is notable for being representative of the latest findings of the latter 17th century, being then subjected to Allen's own ingenious uses and interpretations. It is clear that either before coming to York, or in York itself, Allen encountered good sources. As outlined in the first part of this series ${ }^{11}$ his access to current medical publications and those of the Royal Society may have been through Martin Lister (1639-1712, elected Fellow of the Royal Society [FRS] 1671), who was in York from 1670-1683 or John Dolben (1625-1686 elected FRS 1665), Archbishop of York from 1683 to 1686 , or an associate of such men. Allen only mentions one of his sources by name, Nehemiah Grew (1641-1712, elected FRS 1671), in the section added to the London issue 'The acceleration of the teeth' when venturing into the mystery of tooth eruption. ${ }^{4}$ Grew was not resident in York or Dublin and Allen probably encountered his work in print. ${ }^{12}$ A second edition of Grew's collected lectures on plants delivered to the Royal Society was published in $1682 .^{13}$

In the 'Advertisement to the readers' with which he closes the treatise, Allen says that as far as he knows he is the first to write on his subject, (understandable, though Abulcasis, John of Gaddesden and John Mirfeld had written earlier) and that it is "what is to be expected from one in my circumstances. ${ }^{1,4}$ How much significance should be given to this we cannot know - the circumstances may have been professional difficulties, or he may merely be referring deprecatingly to the fact that he was not educated in the manner of a physician or surgeon.

Dublin was not a stable or safe place to be in the 1680s and one of Allen's printers, the Protestant Samuel Helsham, was killed in Catholic/Protestant unrest in $1689 .{ }^{9}$ In the issue of 1687 , which was for sale in London, Allen's name no longer appears on the title page (although it is still to be found in the text on pages 4 and 44) nor has he fulfilled his promise to expand 'in the next edition' his description of the use of dental tools beyond the one he had already supplied for the 'Polican' [sic] (see

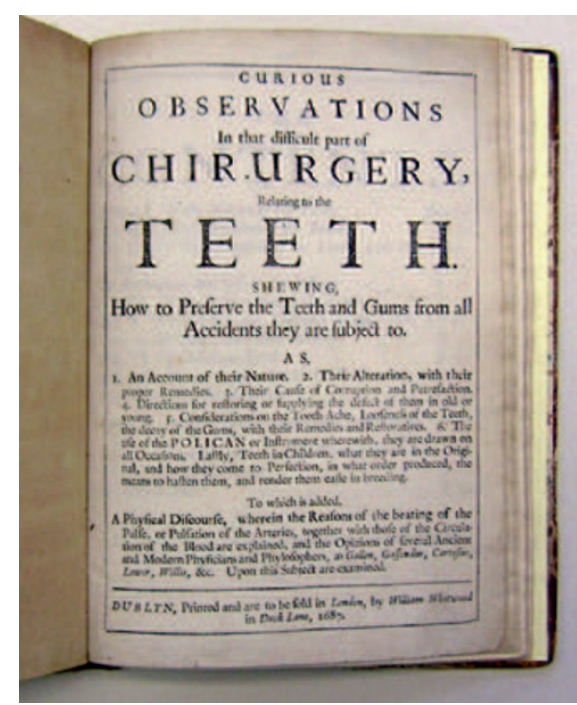

Fig. 1 Title page of the third (London) issue of Charles Allen's Treatise (1687). By kind permission of the Library of the British Dental Association

Bennion for a full illustrated description of this instrument). ${ }^{14}$ It is possible that he was no longer on the scene.

\section{THE TREATISE}

Since the content of the York edition is incorporated in the Dublin edition, this essay is based on the latter and on the London issue, with its new title and new title page. Also new to the Dublin ${ }^{3}$ edition (and retained in the London issue) was a piece 'by an unknown hand' entitled A physical discourse, on the pulse. ${ }^{4}$ The prose style of which is not dissimilar to that of Allen's Treatise. The pagination is continuous and if the writer was not Allen himself then at least Allen had no objection to having his revised second edition appearing in tandem with a scientific treatise of that nature.

The title page of the London issue of 1687 is substantially altered from that of the 1686 edition, not only renaming the Treatise but including in the announcement of the discourse the names of the unknown author's sources. Galen (Claudius Galenus 129-200), Gassendus, (Pierre Gassendi, 1592-1655) Cartesius, (René Descartes, 1596-1650) Lower (Richard Lower FRS, 1631-1691) and Willis (Thomas Willis FRS, 1621-1675) whose Cerebri anatome had only appeared 20 years earlier in $1664,{ }^{15}$ so the piece can be considered as being upto-date. That Allen was also familiar with the work of Lower and Willis is indicated by his detailed knowledge of the vascularisation and innervation of the teeth. 
Lindsay notes that the Treatise was still advertised in the London Catalogue of Books in 1690. By then the two pieces on teeth and the pulse that composed the Dublin printings were in company with a new work on lithotomy. ${ }^{16}$

Both his printers were highly reputable. John White (1635-1715) in York 'over against the Star in Stonegate' (the street where Allen lodged) was to be appointed by William III 'their Majestie's printer for the city of York and the five Northern counties' in $1688^{17}$ and was a 'typographer of renown'18 who printed books in Latin and English for Martin Lister FRS. ${ }^{17}$ Samuel Helsham (-1689) had joined Andrew Crook in 1685 in Dublin and were Assigns of the King's Printer. ${ }^{19}$ They printed a tract for William Molyneux (FRS, 1656-1698) ${ }^{20}$ in the same year as Allen's, and were associated with a proposed Folio edition of John Ray's (FRS. 1627-1705) History of plants. ${ }^{19}$

After a dedication to the physicians, surgeons and apothecaries of the city of Dublin, (not of course present in the York edition) Allen introduces his work with a statement in a proem that he is writing for the public good. The preservation of the teeth being essential for speech, and 'so necessary in the preparing of food, that the want of such a help hinders a true concoction of the Aliments in the Stomach; whence do proceed indigestions, and abundance of Crudities very noxious to the body of man; as being the seed of most of those innumerable Diseases and Infirmities, whereby life is not only made troublesome to us, but also considerably shorter than it would otherwise be. ${ }^{1,3,4}$

In the text Allen introduces dental terms to the lay and professional reader that are still current, for example patient, practice, gums, enamel, root, socket, alveolus, incisors, canines, molars, decay, artificial teeth, transplanting, inoculation and dentifrice. Where he does not use such terms his descriptions are clear enough for the current terminology to be supplied by the 21st century reader; 'every tooth has its socket distinct from all the rest by a thin production of the jaw-bone passing between the Teeth, ${ }^{1,4}$ or; '[each root] has a little channel that goes up to the head of the tooth, where they are united together, and make but a single cavity',4 or; 'if the Tooth be drawn, the gathering will appear at the end of its Stump like a little Bladder. ${ }^{1,4}$
The general and dental anatomy covers the arterial supply to the teeth from the carotids, the venous from the jugular and the nerve from the fifth pair. The previous paper in the series shows how recent the dissections which demonstrated this (1664) and the discovery of the capillaries (1661) had been. ${ }^{11}$ Capillaries described by Malphigi (1628?-1694. elected FRS 1669) ${ }^{21}$ closed William Harvey's (1578-1657) circuit of the blood. ${ }^{22}$

Most remarkable is his description of the microscopic parts of the pulp and dentine. Van Leeuwenhoek's (1632-1723, elected FRS 1680) illustration of human dentine had been published as recently as $1677^{23}$ where he merely describes it as a set of pipes, whereas Allen gives considerable detail. The identification of the 'membrane that invests the cavity of the tooth' may even be his own and it is clear he is referring to the odontoblast layer and not to the periodontal membrane (ligament). ${ }^{1,4}$

The seven 'sections' (his term) into which he divides his Treatise are also innovative, a fact easily overlooked until it is remembered that he had no model. He covers in order the subjects of dental anatomy, periodontology, decay conservation and extraction, prosthetics and implants, toothache and dental pathology, paediatric dentistry and simple orthodontics, and the phenomenon of tooth eruption. Within these headings he introduces theories - for example on the mystery of eruption - and advice based on his scientific explanations, particularly on scaling, extraction and conservation.

Allen makes very clear that he knows he will have made errors, but even these are informative. He states that there are two types of dentinal tubule; 'pores, or small channels', ${ }^{1,4}$ which communicate. This error arises from his belief that the tubules carry a blood supply and there must therefore be 'arteriols' [sic], 'arterial capillaries' and 'venous capillaries'. He devotes considerable space to the causes of toothache and damage to the teeth resulting from blocked pores in the teeth (apparently including the crown). All the rest of the body transpires, so the tooth must do also, and when this is prevented pressure builds up.

As for the nerves, which he and most others believed to be hollow message carriers, (the Royal Society has in its records the manuscript of a lecture delivered on the subject by Nehemiah Grew in $1675^{24}$ and even Luigi Galvani's [1737-1798] work perpetuated some of the error until Allesandro Volta [1745-1827, FRS 1791] clarified the matter), pathological change in the teeth would inevitably affect the brain - dental pain being a multifactorial phenomenon; 'it is but rarely that a Toothake is found simple, or uncompound. ${ }^{4}$

He distinguishes between motor and sensory functions of the nerves, noting that in the teeth 'the faculty of motion is not exercised'.

\section{ALLEN ON TEETHING}

The practical side of Allen's advice on teething (cutting the gums to release the new teeth) is difficult to absorb until it is realised with what dread the natural process was regarded at the time. The association between teething and death was firmly established in the minds of 17th century people. Evidence of this is to be found in the posting of bills of mortality in public places in London during the plague year of 1665. In one week in September 1665 there were 7,165 deaths from plague, 309 from fever, 134 from consumption and 121 from 'teeth. ${ }^{25}$ In other words, deaths during the teething years were third on the list once the abnormal multitude of plague deaths is removed from the bill. In the General Bill for the year as a whole, 'teeth and worms' are lumped together as the cause of death of 2,614 souls, ${ }^{26}$ third again after consumption and fever once plague is discounted.

\section{THE SUCCESS OF THE TREATISE}

A clear idea of the success of Allen's little treatise is given by the survival of so many copies, unlike Chettle's Kind-Hart fiction noted in an earlier paper. ${ }^{27}$ Only two of the first York edition may have survived, but Cohen, in his authoritative introduction to his privately printed facsimile of The operator for the teeth, recorded five of the Dublin edition and 15 of the London issue. ${ }^{7}$

Some of the success of the London issue may lie in the new title page probably composed by William Whitwood, Allen's London book-seller (Cohen noted that for the copy in the Bodleian Library the Dublin frontispiece had been cut out and the new glued in). Whitwood had published the first edition of William Winstanley's (c. 
1628-1698) miscellany with a somewhat cumbersome title in $1683 .{ }^{28}$ It had then been re-published elsewhere as Historical rarities and curious observations domestick and foreign in $1684 . .^{29}$ In giving Allen's treatise a similar title Whitwood was following fashion.

This impression is reinforced when it is noted that two contributors to Philosophical Transactions, each a secretary to the Royal Society, were known as 'learned and curious' in 1686, and that $A n$ account of several curious observations and experiments, concerning the growth of trees was published in the Transactions that year. ${ }^{30,31,32}$ There is no doubt that it was an up-to-date term for Whitwood (or possibly Allen) to employ, and in his Advertisement of books (bound in with Allen's Treatise), the treatise on lithotomy advertised in the London issue is described in the same words that are used for Allen's as 'that Curious, but Difficult part of Surgery'.

The clinical content was always sketchy, but now a fashionably curious London reader was explicitly invited to join in the scientific explanations and musings of the author, as much as to regard the work as a practical guide.

\section{SUMMARY}

It is a matter for regret that so little is known of an operator who has left us with so much evidence of the scientific leanings of a person apparently practising dentistry as his primary profession. This work to examine characteristics of British dentistry in their earliest form and Charles Allen's Operator for the teeth offers a clear insight into a strand woven into the subsequent fabric of dentistry in England, one very different from the practical side of the profession in which Fauchard and his followers and imitators excelled over the channel.

This characteristic is apparent in the 18th century in Berdmore ${ }^{33}$ and Woofendale, ${ }^{34}$ who carried out in vitro experiments on dentifrices and acids; Spence the elder (whose scientific bent was particularly noted by that waspish biographer of John Hunter FRS, Jesse Foot ${ }^{35}$ ); Hunter himself, an honorary dentist (Spence and Hunter were both North Britons, but based in London); the Tomes, father and son (both
FRS) in the 19th Century, and John Mclean in the 20th century.

Charles Allen's assumption was that dental operators based their activities on science. Not that they should do, but that they did.

\section{BIBLIOGRAPHY}

High quality reproductions of the original text of the York edition of Allen's Operator for the teeth of 1685, and of the London issue of the Dublin edition of Curious observations 1686/7, may be found respectively at http://www.dentaljuce. com/fruit/page.asp?pid=355 (accessed January 2013) and http://digital.library. villanova.edu/Joseph\%20McGarrity\%20 Collection/Joseph\%20McGarrity\%20 Books/JosephMcGarrityBooks-00115.xml (accessed January 2013).

The Philosophical Transactions of the Royal Society may be found at http:// rstl.royalsocietypublishing.org/ (accessed January 2013).

The kind assistance of the Library of the Royal Society and the librarians and curators of the British Dental Association is gratefully acknowledged.

1. Allen $\mathrm{C}$. The operator for the teeth. York: John White, 1685

2. Samson E. Progressive practice, a treatise on dental economics. London: Cottrell, 1931.

3. Allen C. The operator for the teeth. Dublin: Andrew Crook and Samuel Helsham, 1686.

4. Allen C. Curious observations in that difficult part of chirurgery relating to the teeth. Dublin: printed Crook \&t Helsham, issued London: W. Whitwood, 1687

5. Ware J. The works of Sir James Ware concerning Ireland (revised and improved). Volume III. Dublin: A. Reilly, 1746

6. Grieve M. Leyel C F. A modern herbal: the medicinal, culinary, cosmetic and economic properties, cultivation and folk-lore of herbs, grasses, fungi, shrubs and trees with all their modern scientific uses. London: Cape, 1931.

7. Cohen R. The operator for the teeth by Charles Allen. Reprint of 1685 edition with an introduction by Ronald Cohen. London: Dawsons of Pall Mall, 1969

8. Weinberger B W. Dental literature: its origin and development. J Dent Res 1924; 6: 305-388.

9. Lindsay L. Curious observations on the teeth by Charles Allen, with a short introduction by Lilian Lindsay London: John Bale, Sons and Danielsson, 1924.

10. Hillam C. Allen, Charles (fl. 1685-1687). In Oxford dictionary of national biography, Oxford: Oxford University Press, 2004. Online entry available at http://www.oxforddnb.com/index/56/101056843 (accessed January 2013).

11. Bishop M. Ars scientia mores: science comes to English dentistry in the seventeenth century. 1. Medical publications and The Royal Society. Br Dent J 2013; 214: 181-184.

12. Grew N. The anatomy of vegetables begun with general account of vegetation, founded thereon. London: Printed for Spencer Hickman, 1672.

13. Grew N. The anatomy of plants (comprising the anatomy of vegetables begun, the anatomy of roots, the anatomy of trunks, the anatomy of leaves, the anatomy of flowers, the anatomy of fruits, etc) with an idea of a philosophical history of plants; and several other lectures, read before the Royal Society. 2nd ed. London, 1682.

14. Bennion E. Antique dental instruments. London: Sotheby's Publications with Philip Wilson, 1986.

15. Willis T. Cerebri anatome. London: James Flesher for John Martyn and James Allestry, 1664.

16. Tolet F. Lithotomy: or a treatise of the extracting of the stone out of the bladder. A. Lovell (trans). London: William Whitwood, 1689.

17. Davies R. A memoir of the York Press: with notices of authors, printers and stationers in the sixteenth, seventeenth and eighteenth centuries. Westminster: Nichols and Sons, 1868

18. Roos A M. Web of nature: Martin Lister (1639-1712), the first arachnologist. Leiden: Brill, 2011.

19. Plomer H R. A dictionary of the printers and booksellers who were at work in England, Scotland and Ireland from 1668-1725. Oxford: Oxford University Press, 1922.

20. Molyneux W. Sciotericum telescopicum. Dublin: Crook and Helsham, 1686

21. Malpighi M. De pulmonibus observationes anatomicae. Bologna: 1661

22. Harvey W. Exercitatio anatomica de motu cordis et sanguinis in animalibus. Frankfurt: Guilielmi Fitzeri, 1628.

23. van Leeuwenhoek A Microscopical observations of the structure of teeth and other bones: made and communicated, in a letter by Mr. Anthony Leeuwenhoeck Phil Trans 1677; 12: 1002-1003.

24. Grew N. Disputatio medico-physica de liquore nervoso. Thesis, 1672. Read to the Royal Society on 28 October 1675 .

25. London's bill of mortality (December 1664-December 1665). In children and youth in history. Item \#159. Online document available at http://chnm.gmu.edu/cyh/primary-sources/159 (accessed January 2013) annotated by Lynda Payne.

26. A general bill for this present year, ending 19 of December 1665. London: Company of Parish Clerks, 1665. Online document available at http://upload. wikimedia.org/wikipedia/commons/2/2f/Bill_of Mortality.jpg (accessed January 2013).

27. Bishop M. The ethics of dental practice in London in the sixteenth century. 1. Henry Chettle's Kind-Harts Dreame of 1592. An important lay view. Br Dent J 2012; 213: 27-30.

28. Winstanley W. Histories and observations domestick and foreign or, a miscellany of historical rarities, collected out of approved authors with other remarkable observations. London: Printed for W. Whitwood, 1683

29. Winstanley W. Historical rarities and curious observations domestick and foreign. London: Rowland Reynolds. 1684.

30. Tyson E. Lumbricus hydropicus; or an essay to prove that hydatides often met with in morbid animal bodies, are a species of worms, or imperfect animals. By that learned and curious anatomist Edward Tyson, M. D. and R. Soc. S. Phil. Trans 1686: 16: 179-191, 506-510.

31. Waller R. Some observations made on the spawn of frogs, and of the production of todpoles therein, by the learned and curious Richard Waller, Esq; Reg. S. Secret. Phil Trans 1686; 16: 179-191, 523-524.

32. Brotherton TR H. An account of several curious observations and experiments, concerning the growth of trees; made by Thomas Brotherton, of Hey, in the county of Lancaster, Esq; brought in and read before the R. S. by R. H. Fellow of the said society. Phil Trans 1686; 16: 179-191, 307-313.

33. Berdmore T. A treatise on the disorders and deformities of the teeth and gums. Illustrated with cases and experiments. London: Printed for the author, 1768.

34. Woofendale R. Practical observations on the teeth. London: J. Johnson, 1783.

35. Foot J. The life of John Hunter. London: T. Becket, 1794. http://archive.org/stream/ lifejohnhunter00footgoog\# page/n139/mode/2up (accessed January 2013). 